\title{
Batik Madura: Heritage Cyberbranding
}

\author{
Yuliana Rakhmawati \\ Program Studi Ilmu Komunikasi FISIB UTM \\ yuliana.rakhmawati@yahoo.com
}

\begin{abstract}
Abstrak
Madura dalam perspektif komunikasi bukan hanya ditempatkan sebagai kumpulan etnisitas melainkan juga sebuah entitas budaya yang melakukan konstruksi atas situs, cara hidup(way of life) dan ide-ide. Proses internalisasi, eksternalisasi dan objektivasi dalam rangkaian interaksi bersama melahirkan produk-produk budaya yang mempunyai nilai filosofi. Batik Madura merupakan salah satu situs kekayaan budaya dengan menampilkan warna kearifan lokal ala haute couture. Dalam perjalanan pergaulannya, Batik Madura semakin berkembang dan terlibat secara aktif dalam dinamika derasnya kompetisi pasar. Strategi diperlukan untuk melestarikan Batik Madura bukan hanya sebagai salah satu warisan (heritage) kekayaan budaya melainkan juga sebagai sebuah kekuatan merek (branding) akan kualitas dari situs budaya.
\end{abstract}

Kata kunci: Batik Madura, Heritage, Branding

\section{Pendahuluan}

Batik dan Indonesia adalah dua entitas yang seakan tertanam (embedded). Ragam etnisitas dari ribuan pulau dengan latar geografi, demografi dan interaksi sosial melahirkan situs-situs budaya yang beraneka. Bahkan dalam pergaulan internasional melalui United Nations Educational, Scientific and Cultural Organisation (UNESCO) batik diakui dan ditetapkan sebagai sebagai salah satu situs warisan budaya milik Indonesia yang ditetapkan (Antara, 2009). Batik dalam konteks pluralitas Indonesia hampir dimiliki oleh semua etnisitas diantaranya; batik Solo, batik pekalongan, batik Yogyakarta,batik
Lasem, batik Banyuwangi, batik Cirebon, batik Medan, batik Tanah Liek (Padang), Sasambo (NTT), batik Kalimantan dan sebagainya.

Dalam buku "Batiks and Beyond" , Laurie J Shifrin (2003) menuliskan bahwa batik bukan sekedar kain (fabrics) melainkan sebuah karya seni dengan perlakuan khusus, mulai dari cara memilih bahan mentahnya sampai dengan perawatannya. McCabe (1917); Krevitsky (1964); Stephenson (1993); Kitley (1992); Hanley (2002) menuliskan tentang pengakuan akan orisinalitas, ornamen, seni dalam sebuah karya batik serta masa depan karya ini. 
Selama ini batik dilekatkan sebagai bagian budaya pada beberapa daerah seperti Solo, Yogyakarta, Pekalongan (Vuldy, 1987). Ternyata motif batik Indonesia lebih beragam dari yang selama ini dikenal. Di Jawa Timur, Pulau Madura selain dikenal sebagai pulau garam ternyata memiliki kekayaan situs budaya dalam bentuk batik. Produk batik yang dihasilkan dari Madura memiliki kekhasan mulai dari perbendaharaan motif, warna yang mencolok dan proses produksi. Ragam motif yang dimiliki batik Madura diantaranya pucuk tombak, belah ketupat, rajut, parang, dan aneka flora fauna.
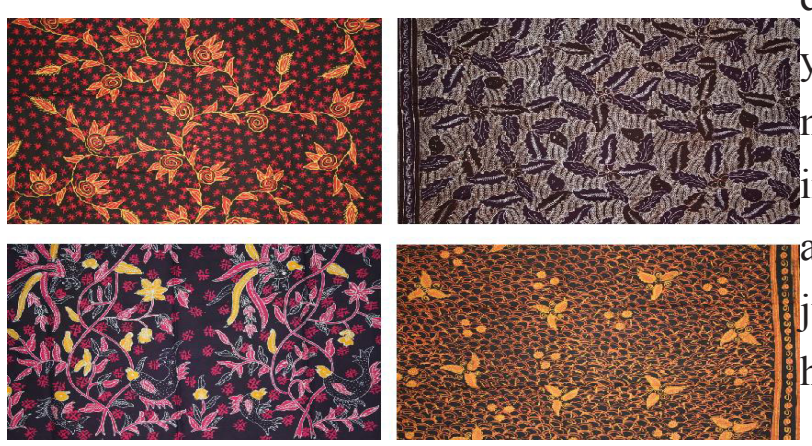

Sumber:http://www.indonesiaberprestasi. web.id/wpcontent/uploads/2010/10/ Madura.jpg

Gambar 1. Motif Batik Madura

\section{Sentra Kerajinan Batik-Setiap} Kabupaten yang ada di Madura memiliki pengrajin batik dengan ciri khasnya masingmasing. Namun yang paling banyak dalam hal jumlah pengrajinnya ada di Kabupaten Bangkalan dan Pamekasan. Sentra batik tulis Tanjung Bumi di Bangkalan, sentra batik tulis Banyumas Klampar, Pamekasan, dan sentra batik tulis Pakandangan Sumenep.
Dalam laman Pemkab Pamekasan bahkan menetapkan desa Banyumas Klampar kecamatan Proppo sebagai desa batik (Disperindag Pamekasan, 2011).

Keunikan batik Madura adalah proses pembuatannya. Batik Gentongan merupakan salah satu tradisi membatik di Madura yang paling terkenal. Istilah gentongan karena proses pewarnaan yang terlebih dahulu direndam dalam wadah mirip gentong. Batik Gentongan cukup dikenal luas karena kekuatan warnanya yang bisa bertahan hingga puluhan tahun. Karena itu, jangan heran bila batik ini harganya cukup mahal dibandingkan dengan batik biasa. Proses pembuatan yang lebih lama membuat batik gentongan menjadi lebih eksklusif. Harga jual batik ini berkisar Rp1,7 juta per helai bahkan ada yang mencapai Rp. 4 juta sampai Rp. 5 juta perlembar kain. Sementara batik celup hanya Rp200 ribu per helai. (Fuad, 2014).

\section{Batik Madura: Situs Heritage}

Sejarah batik Madura telah dikenal sejak zaman kerajaan. Konon, batik Madura mulai dikenal masyarakat luas antara abad ke 16 - 17. Hal ini bermula ketika terjadi peperangan di Pamekasan Madura antara Raden Azhar (Kiai Penghulu Bagandan) melawan Ke' Lesap. Raden Azhar merupakan ulama penasihat spriritual Adipati Pamekasan yang bernama Raden Ismail (Adipati Arya Adikara IV). Sedangkan Ke' Lesap merupakan putera Madura keturunan Cakraningrat I dengan 
istri selir (http://batik-tulis.com/blog/batikMadura).

Dalam peperangan itu, Raden Azhar memakai pakaian kebesaran kain batik dengan motif parang atau dalam bahasa Madura disebut motif leres. Batik parang merupakan kain batik dengan tampilan gambar garis melintang simetris. Ketika memakai kain batik motif parang, Raden Azhar memiliki kharisma, tanpak gagah berwibawa. Sejak itulah, batik menjadi perbincangan di kalangan masyarakat Madura, terutama pembesarpembesar di Pamekasan. Tokoh penting yang dianggap paling berjasa dalam mengenalkan batik ke Madura adalah Adipati Sumenep, Arya Wiraraja. Tokoh ini sangat dikenal karena memiliki kedekatan dengan Raden Wijaya, pendiri kerajaan Majapahit. Perjalanan sejarah batik Madura dewasa ini telah mencapai puncak kejayaan. Apalagi dengan pencanangan Hari Batik Nasional tanggal 2 Oktober oleh Presiden Susilo Bambang Yudoyono.

Batik sebagai produk budaya selain memiliki nilai filosofi dan sejarah yang tinggi juga menyimpan potensi ekonomi kreatif. Batik dapat dikemas dan didistribusikan sebagai komoditas dalam mekanisme pasar. Dalam mekanisme pasar bebas, batik Madura harus bersaing dengan puluhan bahkan ratusan komoditas batik di luar. Untuk dapat bertahan dan berkembang dengan peta persaingan yang ketat, batik Madura mengembangkan metode pemasaran yang inovatif dan ramah konsumen (consumer friendly).
Era teknologi komunikasi 3.0 telah merambah ke dalam segenap bidang. Batik yang selama ini dianggap sebagai komoditas yang dipertukarkan secara tradisional ternyata mampu hadir dalam pasar dengan inovasi teknologi terkini. Batik Madura merupakan salah satu komoditas yang relatif dengan cepat merespon kebutuhan dan keinginan konsumen untuk mengakses sistem belanja yang mudah dan memudahkan. Metode pemasaran dengan basis web sudah mulai diterapkan oleh para pedagang dan pengrajin batik Madura. Coba anda memasukkan kata kunci "batik Madura" dalam mesin pencari di internet, maka dengan segera akan keluar tampilan informasi web, image, maps dalam jumlah puluhan bahkan ratusan.

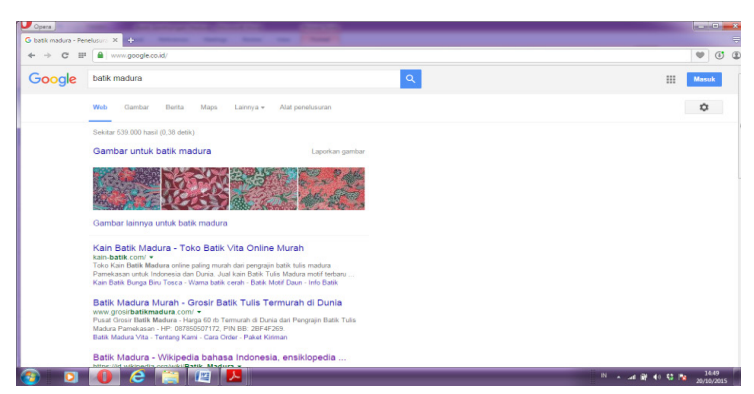

Sumber: screenshot opera

Gambar. 2 tampilan mesin pencari informasi batik Madura

D'alessandro (2001) menuliskan bahwa konsumen menjadi semakin cerdas dan dibebaskan (liberated consumers) atas produk atau jasa yang diinginkan. Internet menjadi salah satu solusi media pemasaran yang memenuhi kriteria ini. Geografis sudah bukan menjadi batasan 
lagi. Rantai pemasaran menjadi semakin sedikit dan yang diterima konsumen adalah kenyamanan yang pada akhirnya dapat mendorong "impulse buying".

Komoditas batik Madura yang ditawarkan dalam situs-situs seperti; $\underline{w w w}$. kain-batik.com; www.produsenbatiktulis. com; www.naura-batik.com; www.batiktulis.com dan banyak lainnya sangat beragam dari batik dengan harga puluhan sampai jutaan perhelai-nya, dari bentuk kain sampai pakaian jadi. Profesionalisme para pedagang tersebut dalam mengelola media cyber ini dalam pemasaran patut diapresiasi. Hal ini salah satunya terlihat dari penggunaan domain .com (komersial) bukan sekedar menempel pada situs penyedia jasa free domain. Informasi yang ditampilkan dalam situs-situs tersebut cukup membantu peminat batik Madura mulai dari harga, fisik produk, cara pemesanan sampai dengan nomor kontak yang dapat dihubungi untuk mendapatkan informasi lanjutan.

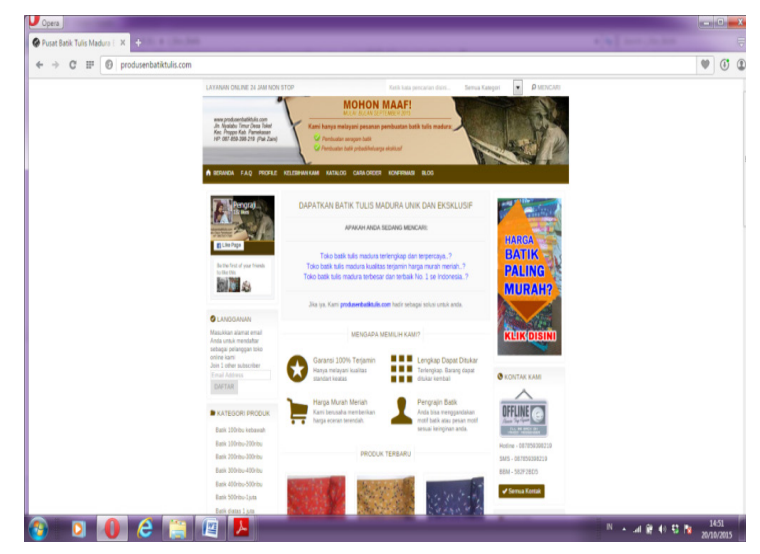

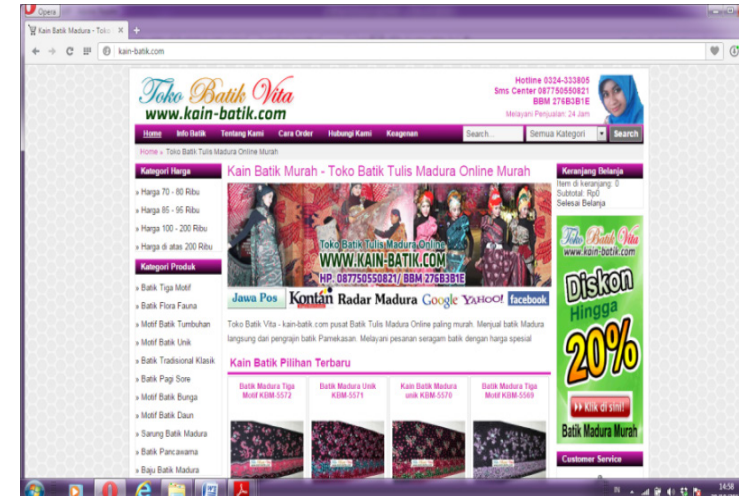

Sumber: kain-batik.com dan produsenbatiktulis.com

Gambar. 3 tampilan situs penyedia produk batik Madura

Sebagai sebuah merek (brand) yang mewakili Madura, batik Madura dapat menunjukkan sisi-sisi adi luhung dari motif, proses pembuatan dan makna filosofinya. Dalam konteks kepariwisataan, hal-hal tersebut dapat menjadikan batik bukan hanya sebagai produk budaya melainkan warisan (heritage) yang perlu dilestarikan. Indonesia sebagai bagian dari ASEAN memiliki potensi wisata heritage dengan market share terbanyak dibandingkan kluster kawasan lainnya Hendersen (2009); Hitchock (2010).

Dalam perspektif komunikasi pemasaran, manajemen pengelolaan warisan (heritage) ini secara profesional dan komprehensif dapat digunakan untuk menjaga dan melestarikan keaslian warisan budaya untuk generasi mendatang sementara di sisi lain dapat menarik pemasok, distributor, regulator serta konsumen (Chhabra, 2010). Merek batik Madura sebagai salah satu atraksi budaya 
memainkan peranan penting dalam iklan produk tertentu seperti iklan mobil pengembangan industri kreatif dengan VW, sepatu Nike, 501's Levi's (Grant, dampak ekonomi dan sosial yang positif.

\section{Cyberbranding: Strategi Membumi- kan Batik Madura}

Batik Madura sebagai komoditas perlu ditempatkan sebagai representasi merek (branding) dari Madura. Inovasi merupakan cerminan yang khas dari perencanaan dan manajemen strategis dari merek (brand) sebuah produk (Chasser, 2010). Merek (brand) dapat dikonsepkan dalam dua pendekatan (1) sebagai ide strategis dari budaya dan (2) kelompok dari ide-ide budaya. Brand dalam konsep yang pertama seperti terkandung dalam iklan-

2006). Sedangkan dalam konsep kedua merek lebih ditekankan sebagai "sesuatu" laten dibelakang produk, seperti: politikus branded, pesohor branded atau bahkan kosmetik organik sebagai branded.

Merek secara evolusional dikenalkan (introduced) dan dipelihara (maintenanced) melalui kerja sama pemasaran dengan beberapa media, diantaranya radio dan televisi (Breckenfeld, 2009). Dalam perkembangan teknologi informasi konsep pemasaran atas merek (brand) juga mengalami pergeseran, salah satunya dengan menggunakan teknologi internet.

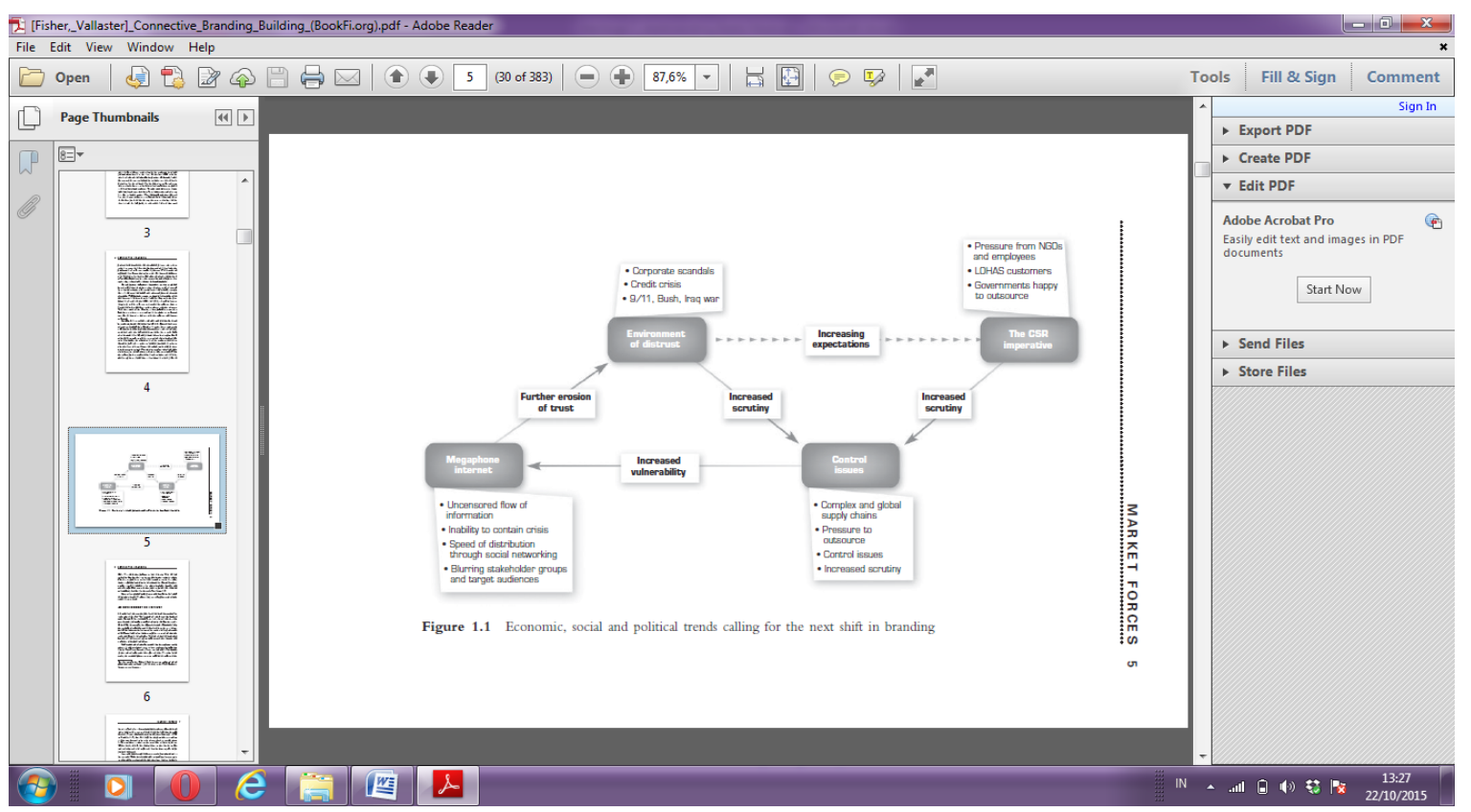

Sumber: Fisher-Buttinger, Claudia; Christine Vallaster. 2008.

Connective Branding. Building Brand Equity In A Demanding World.

Gambar 4. Tren ekonomi, sosial dan budaya dalam branding. 
Setiap merek (brand) mempunyai peluang yang sama untuk berkembang dengan menggunakan media internet. Dalam perspektif komunikasi pemasaran terkini, kontribusi internet terhadap merek (brand) tidak dapat diremehkan. Menjadi merek yang cerdas siber (cyber branding) adalah istilah yang dilekatkan kepada bentuk pemasaran tanpa batasan geografi (no boundaries) dengan menggunakan media internet.

Untuk mejnadi sebuah cyberbrand, bukan hanya memindahkan nama, logo, nama perusahaan dan nilai-nilai serta harapan brand sebelumnya ke dalam media internet. Pemilik merek (brand) perlu merubah cara berfikir dengan memberikan kebebasan kepada konsumen secara alami untuk mengalami kesempatan "merasakan" merek tersebut dalam level interaktif. Dalam hal ini istilah "cyber" kemudian merujuk pada bagian pelayanan interaktif atas informasi yang diperlukan konsumen dengan menyediakan menu live chat, response terhadap surat elektronik dari konsumen, menjawab FAQs (pertanyaan dari konsumen) sepanjang waktu 24/7 (Breakenridge, 2001). Internet dapat menjadi media untuk meningkatkan loyalitas konsumen akan produk tidak terkecuali Batik Madura. Harden (2009) menyebutkan dengan contoh studi kasus atas brand-brand yang menggunakan internet sebagai sarana iklan (advertising) yang mempunyai kekuatan lebih besar mengingat karakteristik media siber yang melampaui media tradisional.
Potret batik Madura selama ini belum merambah pada industri skala besar. Hampir semua masih industri kecil menengah (small medium entreprises). Dalam era pasar global perdagangan elektronik (e-commerce) menjadi salah satu solusi kepada UMKM Batik Madura. Pasar global bukanlah sesuatu yang harus dihindari oleh pengusaha UMKM. Sebagai contoh industri busana di Bali sudah melaukan langkahlangkah strategis untuk bergabung dalam pasar global (Hassler, 2005). Abajo (2011) berpendapat bahwa dengan perencanaan yang memadai maka UMKM dapat bersaing dalam pasar internasional.

Batik Madura perlu melakukan diferensiasi atas merek (brand) yang selama ini dikenalnya. Tai (2008: 286) menuliskan bahwa diferensiasi bukanlah tentang pelayanan (service), kualitas (quality) maupun orangnya (people) melainkan tentang strategi. Kepemimpinan dalam penjualan (sales), teknologi (technology), kinerja (performance), spesialisasi dan muatan heritage. Batik Madura sebagai warisan adalah investasi budaya yang perlu diepertahankan. Biaya keuntungan (cost advantage) dalam nilai produk bukanlah sekedar menggali keuntungan finasial jangka pendek melainkan ditempatkan sebagai investasi jangka panjang. Roll (2006) menyebutkan sebagaimana brandbrand Asia (eastern) dengan nilai ideide dan makna filosofi yang dalam dapat menjadi brand yang kuat. Batik Madura dengan perencanaan model, identifikasi stakeholders, visi yang jelas, eksplore 
teknologi terbaru dan langkah strategis lainnya dapat juga bergabung menjadi brand kuat Asia seperti Singapore Airlines, Aman Resort, Shiseido, Samsung.

Sebagai sebuah brand maka Batik Madura memerlukan pengelolaan yang berkelanjutan. Dengan mekanisme pengelolaan yang tidak menggunakan acuan dan standar maka akan membuat brand tersebut hanya menjadi seperti brand lainnya. Nakai (2008) menyebutkan bahwa merek (brand) dapat gagal apabila melakukan melakukan kesalahan dalam manajemen. Beberapa kesalahan tersebut sub sistem pendukungnya seperti manajerial, pemberdayaan, fokus, ketelatenan, kerangka kerja, bagian yang tidak suportif, ide yang tidak berkembang.

Pemasaran Batik Madura dengan cyberbranding pada dasarnya merupakan langkah strategis untuk menjangkau publik yang lebih luas dan tanpa batas (borderless). Mekanisme pertukaran informasi on demand antara penjual dan pembeli Batik Madura melalui media internet hanya sebagai langkah awal untuk mendekati pasar. Bahwa terdapat segmen pasar yang lebih suka untuk bertransaksi secara tradisional "ada barang ada uang" maka para pengusaha Batik Madura dan regulator dapat secara adaptif melakukan road show ke daerah-daerah untuk mengenalkan dan menginisiasi program pemasaran langsung (direct selling).

\section{PENUTUP}

Konsep situs budaya melekat didalamya adalah ideologi dari para konstruktor. Bahkan dalam selembar kain "amba" dan "titik" terdapat muatan nilainilai filosofi yang kental. Etika, moral, toleransi, bersahabat dengan alam adalah nilai-nilai kepatutan yang dilekatkan pada keindahan estetika penciptaan situs tersebut. Proses merangkai titik-titik menjadi sebuah nirmana yang bukan sekedar melahirkan fisik produk melainkan juga terdapat matra didalamnya. Proses panjang yang melahirkan produk dengan nilai oleh kurator diakui sebagai sebuah kreativitas dengan idealisme.

Kesabaran dan ketelatenan atas sebuah karya seni dalam pembuatan sebuah batik tulis, di Madura terdapat batik Genthongan, adalah cerminan bahwa membatik bukanlah sekadar membuat komoditas yang mempunyai nilai tukar finansial melainkan budaya yang ditradisikan dalam konteks warisan (heritage). Dalam konteks interaksi industri kreatif, Batik Madura mulai mendapatkan tempat tersendiri pada para peminatnya. Para penggemar Batik Madura ini bukan hanya dari kalangan emic Madura melainkan juga secara etik telah menjadi komoditas inklusif.

Batik Madura berevolusi menjadi sebuah komoditas dengan pelekatan merek (brand) segenap warna Madura yang dibawanya. Dalam perkembangannya Batik Madura semakin mendekati teknologi terkini, salah satunya dengan 
menggunakan teknologi siber. Keuntungan penggunaan media ini adalah sebagai inisiasi pengembangan cyber branding atas komoditas ini agar semakin mudah diakses dan dimiliki oleh publik luas. Tetapi disisi lain semakin mudahnya masyarakat luas mendapatkan akses untuk memiliki produk ini diharapkan tidak dimanfaatkan oleh pelaku industri menurunkan kualitas dan nilai yang "dibawa" oleh Batik Madura mengingat batik dan Batik Madura termasuk didalamnya adalah sebuah warisan budaya (heritage) aset bangsa yang bahkan diakui secara internasional oleh badan dunia.

\section{DAFTAR PUSTAKA}

Abajo, Beatriz Sainz de; Enrique Garc'1a Salcines; F. Javier Bur'on Fern'andez; Miguel L'opez Coronado; Carlos de Castro Lozano. 2011. "The Leap of a Provincial SME into the Global Market Using E-commerce: The Success of Adequate Planning" dalam Ficarra, Francisco V. Cipolla et.al (ed). Human-Computer Interaction, Tourism and Cultural Heritage. Berlin. Springer.

Anonim. 2011. Batik dari http://disperindag.pamekasankab.go.id/?page_id=113 diakses 20 Oktober 2015.

Bambang. 2009. Unesco Setujui Batik Sebagai Warisan Budaya Indonesia dari http://www. antaranews.com/berita/153756/unesco-setujui-batik-sebagai-warisan-budayaindonesia diakses pada 22 Oktober 2015.

Breakenridge, Deirdre. 2001. Cyberbranding : brand building in the digital economy. Upper Saddle River. Prentice Hall PTR.

Breckenfeld, Del. 2009. The Cool Factor. Building Your Brand's Image Through Partnership Marketing. Hoboken. John Wiley.

Chasser, Anne H; Jennifer C. Wolfe, Esq., Apr. 2010. Brand Rewired. Connecting Intellectual Property, Branding, And Creativity Strategy. John Wiley \& Sons, Inc.

Chhabra, Deepak. 2010. Sustainable Marketing of Cultural and Heritage Tourism. London. Routledge. 
D'alessandro, David F.; Michele Owens. 2001. Brand Warfare 10 Rules For Building The Killer Brand. Lessons For New And Old Economy Players. New York. McgrawHill.

Fisher-Buttinger, Claudia; Christine Vallaster. 2008. Connective Branding. Building Brand Equity In A Demanding World. A John Wiley \& Sons, Ltd., Publication.

Fuad, Hafid. 2014. Batik Madura Joko Tole Tembus Pasar Mancanegara sumber :http:// ekbis.sindonews.com/read/942913/36/batik-Madura-joko-tole-tembus-pasarmancanegara-1419686603 diakses 17 Oktober 2015.

Grant, John. 2006. The Brand Innovation Manifesto: How to Build Brands, Redefine Markets and Defy Conventions. England. John Wiley \& Sons Ltd.

Hanley, James. 2002. The art of batik. Irish Arts Review (2002-), Vol. 29, No. 1 (Spring (March - May 2012)), pp. 118-119.

Harden, Leland; Bob Heyman. 2009. Digital Engagement. Internet Marketing That Captures Customers And Builds Intense Brand Loyalty. Amacom.

Hassler, Markus. 2005. Global Markets, Local Home-Working: Governance and Inter-Firm Relationships in the Balinese Clothing Industry. Geografiska Annaler. Series B, Human Geography, Vol. 87, No. 1 (2005), pp. 31-43.

Henderson, Joan C. 2009. "The Meanings, Marketing, And Management Of Heritage Tourism In Southeast Asia" dalam Dallen J. Timothy; Gyan P. Nyaupane (Ed). Cultural Heritage And Tourism In The Developing World. A Regional Perspective. Routledge.

Hitchcock, Michael; Victor T. King; Michael J. G. Parnwell. 2010. "Heritage Futures" dalam Michael Hitchcock; Victor T. King; Michael Parnwell (ed). Heritage Tourism in Southeast Asia. Copenhagen S. NIAS Press.

Kitley, Philip. 1992. Ornamentation and Originality: Involution in Javanese Batik Indonesia, No. 53 (Apr., 1992), pp. 1-19.

Krevitsky, Nik. 1964. The Art of Batik Today. Art Education, Vol. 17, No. 8 (Nov., 1964), pp. 33-35.

McCabe, Lida Rose. 1917. When Designer and Manufacturer Meet. The Art World, Vol. 2, No. 3 (Jun., 1917), pp. 290-292.

Nakai, Noriyuki. 2008. "Why does branding fail? Ten barriers to branding" dalam Bernd H. Schmitt; David L. Rogers (ed). Handbook on Brand and Experience Management. 
Edward Elgar. Cheltenham, UK.

Roll, Martin. 2006. How Asia Builds Strong Brands. Palgrave McMillan.

Shifrin, Laurie J. 2003. Batiks And Beyond. The Patchwork Place. Martingale Company.

Stephenson, Nina. 1993. The Past, Present, And Future Of Javanese Batik: A Bibliographic Essay. Art Documentation: Journal Of The Art Libraries Society Of North America, Vol. 12, No. 3 (Fall 1993), Pp. 107-113.

Tai, Jacky; Wilson Chew. 2008. Killer Differentiators 13 Strategies To Grow Your Brand. Singapore. Marshall Cavendish Business.

Vuldy.Chantal. 1987. Pekalongan: Batik Et Islam Dans Une Ville Du Nord De Java Dalam John N. Miksic (Review). Journal Of Southeast Asian Studies, Vol. 20, No. 2 (Sep., 1989), Pp. 336-338.

Internet :

https://id.wikipedia.org/wiki/Batik_Madura diakses 20 Oktober 2015

http://batik-tulis.com/blog/batik-Madura diakses 20Oktober 2015 